Please do not remove this page

RMIT

UNIVERSITY

\title{
The impact of purchase goal on wine purchase decisions
}

Dobele, Angela; Greenacre, Luke; Fry, Jane

https://researchrepository.rmit.edu.au/esploro/outputs/9921859110001341/filesAndLinks?institution=61RMIT_INST\&index=null

Dobele, A., Greenacre, L., \& Fry, J. (2018). The impact of purchase goal on wine purchase decisions.

International Journal of Wine Business Research, 30(1), 19-41.

https://doi.org/10.1108/IJWBR-07-2016-0021

Document Version: Accepted Manuscript

Published Version: https://doi.org/10.1108/JJWBR-07-2016-0021

Repository homepage: https://researchrepository.rmit.edu.au

(c) Emerald Publishing Limited

Downloaded On 2023/04/27 00:52:42 +1000

Please do not remove this page 
Thank you for downloading this document from the RMIT Research Repository.

The RMIT Research Repository is an open access database showcasing the research outputs of RMIT University researchers.

RMIT Research Repository: http://researchbank.rmit.edu.au/

\section{Citation:}

Dobele, A, Greenacre, L and Fry, J 2018, 'The impact of purchase goal on wine purchase decisions', International Journal of Wine Business Research, vol. 30, no. 1, pp. 19-41.

See this record in the RMIT Research Repository at:

https://dx.doi.org/10.1108/IJWBR-07-2016-0021

Version: Accepted Manuscript

Copyright Statement:

(C) () Emerald Publishing Limited

Link to Published Version:

https://dx.doi.org/10.1108/IJWBR-07-2016-0021 
The Impact of Purchase Goal on Wine Purchase Decisions

\begin{tabular}{|r|l|}
\hline Journal: & International Journal of Wine Business Research \\
\hline Manuscript ID & IJWBR-07-2016-0021.R1 \\
\hline Manuscript Type: & Research Article \\
\hline Methods: & Online Survey, Seemingly unrelated regression \\
\hline Topics: & Wine marketing, Purchase indicators, Purchase context, Value judgements \\
\hline \multicolumn{2}{|c}{} \\
\hline
\end{tabular}

SCHOLARONE $^{\text {TH}}$

Manuscripts 


\title{
The Impact of Purchase Goal on Wine Purchase Decisions
}

\begin{abstract}
Purpose: This paper examines the impact of purchasing occasion on product value indicators for a selection of Australian and New Zealand branded wines by Australian consumers. Purchasing occasions are either home (personal and private) or restaurant consumption (personal and public) or as a gift (impersonal and public).
\end{abstract}

Methodology: An online survey is used to understand the changing importance of value indicators based on differing purchase goals. Value indicators were defined as conspicuous or inconspicuous. Conspicuous indicators include corporate advertising, such as the vineyard, region or brand, and are considered the same (or equal) for all recipients. Inconspicuous indicators are less visible and may differ from recipient to recipient, such as referrals. The sample comprised marketing professionals, who are highly educated and likely to be of prime working age (25-55 years). The majority of respondents were Australian-born and described themselves as Anglo-Saxon.

Findings: Conspicuous indicators, such as advertising, are more important for impersonal consumption experiences such as gifts or to drink in public. Less conspicuous, but more trustworthy, indicators, (personal recommendations), are more important for personal consumption experiences. These results offer insight into the indicators of product value that marketers could emphasise in their marketing mixes to target consumers buying with different purchase goals in mind and seek new markets.

Limitations: This study was limited in geographical selection and the methodology comprised an online survey. The nature of the purchase contexts was deliberately kept broad to highlight the overall impact of value indicators.

Originality/value: While there have been some studies centering on wine purchase and consumption in different situations, direct comparisons between contexts are rare. This paper addresses this gap in the literature by comparing consumer behaviour across wine purchase contexts. The value of this paper stems from deepening understanding of the role of context in purchase decision making and the implications for marketing practitioners and clearly identified opportunities for future research.

Key words: wine marketing, purchase indicators, purchase context, value judgments. 


\section{Introduction}

The value of the global wine market is forecasted to be $\$ 303.6$ billion by 2016 , an increase of 17.9\% since 2011 (BusinessWire 2012). Not surprisingly, academe has paid attention to the fluctuations and forces within this valuable industry. Lockshin and Corsi reporting 'over 200 wine marketing studies have been published in academic journals in the past 20 years' (2012, p. 16). Previous research has considered the relevance of purchase goal on consumption practices of wine (Ritchie, 2007, Jaeger et al., 2009, Maynard and Davidson, 2009, Bruwer et al., 2013). However, comparisons between purchase goals are rare. An understanding of purchase goals, the contexts in which the purchase occurs, are important to understanding consumer decision-making and consumption practices. Such knowledge will have a greater impact on marketing strategy, advertising/branding approaches and value adding (Keel and Padgett, 2015).

Understanding the key drivers of consumer wine perception and consumption behaviour is a major challenge for practitioners and researchers in the domain of wine marketing (Wiedmann et al., 2016). This paper addresses this gap by comparing consumer decisionmaking practices across purchase goals, specifically: how does the wine purchase decisionmaking process vary between different purchasing goals?

\section{Wine complexity}

While price indicates perceived quality (Bligh et al., 2015), judgments about wine also rely on intrinsic and extrinsic cues (e.g. Thomas and Pickering, 2003), for example, performance in wine shows (Dunphy and Lockshin, 1998) or based on vineyard brands (Goldman, 2012) or geographical regions (McCutcheon et al., 2009). Furthermore, wine has evolved to have symbolic lifestyle meanings which can complicate the purchaser's decision-making process (Bruwer et al., 2002, Unwin, 1996 cited by Charters and Pettigrew, 2008) with wine selection and consumption based on a myriad range of perceptions. From wine being the healthier alcoholic beverage, for food pairing and flavour, and sociability (Silva et al., 2015).

The inherent difficulties within the product category have been described by Wiedmann et al., as a 'major challenge for practitioners and researchers in the domain of wine marketing' and a 'consequence of the highly complex nature of wine as a product' which necessitate a 'deeper understanding of the key drivers of consumer wine perception and consumption behaviour'(2016, p 551). 


\subsection{The Importance of Value}

Value is the perceived benefits of a specific product or service, minus the perceived costs, as experienced by the customer within a particular context (Zeithaml, 1998, Vargo and Lusch, 2008). Consumers make value inferences based on a manifold list of potential purchase indicators ranging from 'price, brand name, product attributes, perceived ease of use, versatility, durability, serviceability, performance, and prestige', to judge the 'value of a product' (Brucks et al., 2000, p. 1). They are exposed to value indicators through combinations of marketing, advertising, promotion, packaging and word-of-mouth. Such judgments can be based on objective or subjective knowledge (Morey et al., 2002) and, based on their judgments; consumers select the product that offers the greatest perceived value (Louviere et al., 2000).

Depending on the situation and purchase goal it is possible that some purchase indicators gain importance over others in a fluid structure; that is, indicator importance changes with purchase goal. Conspicuous purchases are made as an 'advertisement of one's income and wealth through lavish spending on visible items' (Heffetz, 2011, p. 1101). However, the term has broader meaning than eye-catching or prominent (Chaudhuri and Majumdar, 2006) to suggest a mode of consumption that enhances social prestige (Veblen, 2007). It is impossible to ignore the potential conspicuous (hedonistic) (Williams and Atwal, 2013) nature of wine purchases in the modern marketplace; from its common presence in social gatherings, its role as representative of national identity (e.g. French Champagne) (Guy, 2007), as a potential for investment (Krasker, 1979), to wine as an obsession (Masset et al., 2015).

Overall, wine consumption has been presented as a taxonomy of wine consumption practices (experience, integration, play and classification) and the context of consumption defined as the experience of the wine consumer (from amateur to experienced) (Groves et al., 2000). Tatzel's (2002) taxonomy of linking materialism to specific consumption dispositions and the work of Richins (1994a, 1994b) found that those high in materialism place higher value on goods to be consumed in public. The consumption of goods that seek to demonstrate the purchase capacity and wealth of an individual is known as conspicuous consumption (Kofi et al., 2009). 


\subsection{Antecedents of Wine Purchasing}

Consumer's understanding of wine quality has been found to be dependent on their involvement level which manifests as substantially different consumption behaviour (Morey et al., 2002, Charters and Pettigrew, 2006).

Wine is a complicated product category, with 'brand hierarchies and many different cues ... that can influence decisions' (McCutcheon et al., 2009, p. 213). Most wine attributes can only be assessed during consumption, so consumers have limited scope to assess value before purchase, hence the reliance on extrinsic cues (Bruwer et al., 2013). Consumers use information to minimise the risk of purchasing poorly and reduce their decision-making costs in an imperfect information environment (Celhay and Passebois, 2011). While researchers do not agree on choice factors' importance, there is an acknowledgment that it likely varies among consumer segments and by consumption occasion (Bruwer et al., 2013).

\section{Purchase Goals and Influence on Behaviour}

From a broad consumption perspective, previous research has demonstrated that consumers will 'incorporate more variety into their consumption decision when their behavior is subject to public scrutiny' (e.g. Ratner and Kahn, 2002, p, 246). Such behavioural changes could be underpinned a desire to manage impressions (Ratner and Kahn, 2001) or the wish to communicate possessions and identities (Belk, 1988).

Wine purchases are influenced by consumers' personal characteristics such as self-image, aspirations and status (Charters and Pettigrew, 2006). Previous research concluded that consumers are particularly price-conscious in restaurants (Bruwer et al., 2013) and when selecting wine as a gift; consumers are concerned with the image of the wine (in particular, the bottle appearance and label) so as not to lose status (Ritchie, 2007). Displays of status is commonly referred to as conspicuous consumption (Woodside, 2012).

Previous studies suggest a relationship between product involvement and consumer behaviour (Morey et al., 2002), leading to segmentation strategies more aligned to particular usage situations. Such situations may also be linked to the public scrutiny aspects identified in the consumption literature (Ratner and Kahn, 2002). Selecting wine in a restaurant/bar can be complex and stressful as a result of the public environment and limited choice/lack of control in wine selection (Ritchie, 2007).

In such situations, consumers may rely on cues, such as grape varietals, awards obtained and price (Corsi et al., 2012). Recommendations (particularly from knowledgeable staff) may 
become more influential, although past research has found that recommendations were less important in bistros, cafés and pubs (Bruwer et al., 2013).

With an impersonal purchase goal, the wine purchaser is buying with another's tastes or preferences in mind, or with a particular gift purpose in mind. Therefore, the use of conspicuous indicators may gain importance. Conspicuous indicators are clearly visible (e.g. the marketing by a vineyard or award stickers on the bottle), and are the same for all recipients. Inconspicuous indicators, such as referrals given by staff or a friend, can differ and are not visible (e.g. across different store locations or amongst different social networks).

Attention was given to three main purchase goals underpinning wine purchases; first, wine purchased for home consumption, deemed a personal (they drink it) and private (in their home) consumption experience. Second, wine purchased and consumed in a public place (restaurant/bar), deemed a personal (they are still the ones drinking it) and public consumption experience. Third, wine purchased as a gift, representing impersonal consumption as the giver is thinking of the consumption of another (although they may share), and the gift is, by nature, public.

The conceptual framework integrates these elements from the literature, Figure 1. Individuals' characteristics, motivations, personal values and the extent of their product involvement (regarding their knowledge) and some notion of product expertise or confidence (e.g. palate, experience) combine to influence what they consider the most relevant selection of value indicators, depending on the purchase goal. The selected value indicators determine their perceptions of symbolic and experiential dimensions associated with consumption and ultimately influence the final purchase decision.

The purchase goals form the 'lens' through which the relative importance of each value indicator is determined by the individual, and it, therefore, has a key role in determining the importance of particular factors in perceptions of wine and ultimate purchase decisions. Given wine's hedonistic characteristics, are conspicuous indicators of more importance, valued more highly, over inconspicuous indicators?

Research Question 1: indicators (conspicuous and inconspicuous) will have differing values to, and, influences on, consumers' perceptions of a wine's symbolic/experiential qualities depending on the purchase goal.

This questions drills into the three different purchase goals and assumes that the more personal the consumption (at home), the more important inconspicuous purchase indicators 
will become, compared with more public the consumption (in a restaurant or for a gift), where conspicuous indicators become more important. Each purchase goal and purchase indicator are considered as separate hypotheses.

\section{INSERT FIGURE 1}

Product value indicators are cues used by consumers to estimate the value of products, as mentioned above. A conspicuous indicator is one that is highly visible in the marketplace, and a purchaser may safely assume that most other purchasers in the market would have also been exposed to this indicator. Eight conspicuous indicators were developed from preliminary research and extant literature:

i. price per bottle excluding discounts, promotional sales or bulk quantity (e.g. Dimson et al., 2015, Lecat et al., 2016, Ginon et al., 2014);

ii. availability, considered as if the wine is exclusive or rare compared with more readily available wines (e.g. Halonen et al., 2014);

iii. grape variety to account for purchasers with preferences for a particular grape variety or blend (e.g. Rowley, 2016, Ginon et al., 2014);

iv. packaging, namely the label on the bottle (e.g. Corduas et al., 2013);

v. brand name, considered as the name on the label that may incorporate, for example, a vineyard or geographical region (e.g. Moulard et al., 2015, Kelley et al., 2015, Ginon et al., 2014);

vi. marketing/advertising/promotion comprising any kind of corporate communication that a purchaser might have seen before the purchase excursion, therefore excluding in-store promotions (e.g. Koch et al., 2013, Chrysochou and Jørgensen, 2016, Festa et al., 2016);

vii. in-store promotions (e.g. Szolnoki and Hoffmann, 2014, Bues et al., 2017);

viii. newspaper or other media reviews (e.g. Azar et al., 2014).

Inconspicuous indicators are those that may significantly differ in their diffusion among purchasers. For example, while purchasers may have been exposed to the same television commercial, read the same review or seen the same in-store promotion, they will not have been exposed to the same recommendations from friends, family or colleagues. Recommendations from wine professionals or bottle shop employees were also considered to be inconspicuous as they could differ substantially across stores, regions and staff. 


\section{Methodology}

\subsection{The Pacific Wine Industry}

This research focuses on the wine sector of the Southern Hemisphere, in particular, the Australian and New Zealand wine industries. Wine from the southern hemisphere, the socalled 'new world' wines is of increasing importance from economic (particularly export) and cultural perspectives and 'the wine industry in the Southern Hemisphere Pacific Ocean is an important research context as few studies ... have been conducted in this part of the World' (Felzensztein et al., 2014, p. 839). Two countries' wine was selected, Australia and New Zealand based on their considerable reach within the global wine market (Trade Data \& Analysis, 2013, Howland, 2014).

The Australian wine industry gained a reputation for 'approachable, yet high quality, characterful wines of every possible style' (Clarke, 2002, p. 286), it is one of the few countries that produces every one of the major wine styles (including Shiraz, Cabernet Sauvignon, Chardonnay and Sauvignon Blanc (Wells, 2007). The Australian wine industry is consistently one of the top ten wine producing countries in the world and has become a viable challenger of the traditional old world wine industry (Morrison and Rabellotti, 2014).

New Zealand was selected for its rather unique wine industry, 'accounting for less than one percent of global output and exports' (Felzensztein et al., 2014, p. 840) it has, nonetheless, 'built on a premium reputation' and inextricably bound to the reputation of the country leading to the perception that 'New Zealand wine is of iconic status' (New Zealand Wine, 2014, p. 4). Such a foundation is potentially risky; 'without consumers willing to pay more on average for New Zealand wine than for almost any other country's wine, wine production in New Zealand would not be an economic proposition' (New Zealand Wine, 2014, p. 4).

\subsection{Wine Labels}

With so much product variety in the wine market (Morrison and Rabellotti, 2014), the labels were selected to capture the broad range of characteristics of wines available:

Research Question 2: wine labels represent value indicators for consumers and, as such, will influence consumers' perceptions of a wine's symbolic/experiential qualities.

This design covers a wide variety of likely consumer choice sets across purchase goals. The selected wines came from six regions in Australia and New Zealand, and a variety of grape 
type were represented as different wine types appeal to people with different tastes. In addition to the major types of red and white table wines, a fortified wine was also included.

Pricing wines can be a difficult exercise. What is expensive to one is potentially a bargain for another. Historically, wine pricing considerations included costs of products, government influence, product differentiation, pricing image sought for the product, behaviour of relevant agents (e.g. distributors or suppliers), competition and the wine buyer and consumer behaviour (Adapted from Kotler et al., 1989 by Edwards and Spawton, 1990, 11).

The Academy of Wine Business Research suggests nine wine pricing segments (AWBR, 2005) and a revised price segmentation model suggests three broad segments (luxury, premium and everyday) (Wine Folly, 2016). Since few restaurants carry wine in the in the everyday price range (including jugs or boxed wine), labels were selected from the midpremium range (defined as low for this study and priced $(\$ 10->15))$, from the ultra-premium range (defined as our medium price range $(\$ 15->20)$ ) and two categories for the most expensive price ranges, high (\$20->30) and luxury (\$30 and over) price bands.

An online search of not less than five distributors of each wine label was then used to calculate the average (considered indicative price) for each wine included in the study. All prices were converted to Australian currency for comparison within the study but expressed as either $\mathrm{A} \$$ or $\mathrm{NZ} \$$ in the survey.

About half of the wine labels displayed additional information (Figure 2) that could be perceived as making those labels more distinctive or indicating higher quality. Table 1 provides a summary of the characteristics of each wine as displayed on the label.

INSERT FIGURE 2

INSERT TABLE 1

\subsection{Survey}

An online survey was developed to test the research hypotheses, and respondents were emailed an invitation to complete (by clicking on the link or pasting the URL into a browser). Online surveying was chosen as the target population could be accessed easily by the invitation email, the method enabled snowball sampling, was time-saving and allowed anonymity through the web submission process (Schonlau et al., 2002). Within a three-month window, 298 useable survey responses were received and included in the study. 
Completion of the survey took approximately 25-30 minutes and comprised four sections: first, demographic profile (age group, gender and ethnicity), allowing respondents to complete quickly followed by a short section on wine consumption and familiarity. During pre-testing, this section was changed to incorporate comparative statements about wine consumption rather than specific volumes or measures. Test respondents found it difficult to remember quantities of alcohol consumed in the past and became focussed on varietals rather than consumption. The third section comprised 14 indicators of wine value (adapted from past research (e.g. Thomas and Pickering, 2003, Smeets, 2004, Lockshin et al., 2006)) contextualised for each of the three consumption scenarios. Respondents used a seven-point Likert scale, with a neutral center anchor.

The final section, focussed on the wine labels. Respondents were presented with colour images of labels from 15 wine bottles readily available in the Australian and New Zealand markets at the time of the study (Figure 2). Using a Likert scale, respondents rated the extent to which they agreed (or disagreed) that each wine was likely to be tasty, high quality, high value for money, confer a high status upon the wine drinker and be exclusive.

Seemingly Unrelated Regression (Zellner, 1962) was used to capture interrelationships between ratings that arose from other non-measured characteristics of the respondents. This technique consists of several regression equations, each with a dependent variable and potentially different sets of exogenous explanatory variables (Zellner, 1963, Fiebig, 2001). Further, this technique allowed for error terms across equations to be correlated, needful because the same individuals provided the ratings on each (dependent) variable and some individuals might have been predisposed towards strong views and only used the strongly agree (=7) option for all variables, while others might have had no strong opinions and tended to use the neutral central category (Peremans and Van Aelst, 2016).

\section{Results and Discussion}

\subsection{Sample characteristics}

The sample was almost equal regarding gender (53\% female) and between $45-54$ years (27\%) followed by 35-44 (25\%) and 25-34 years (23\%). Most respondents were born in Australia $(64 \%)$ and lived there (82\%), and aligned with Anglo-Saxon (88\%) (Table 2). 
INSERT TABLE 2

Product involvement was indicated by levels of wine consumption, knowledge and confidence. Respondents were most likely to agree to some extent that, about their family and friends, they consumed a lot of wine $(66 \%)$ though perceptions of what constitutes an appropriate level of alcohol consumption differ (de Visser and McDonnell, 2012). Respondents were most likely to agree to some extent that compared to family and friends, they considered themselves familiar with wine (73\%) and, most likely felt they could detect quality differences between different brands of wine (about three-quarters). For each of these three indicators, about $20 \%$ strongly agreed with the statements and could be considered well-informed, skilled and experienced wine consumers (Table 3). Those who disagreed with the statements are considered novices when it comes to purchasing and consuming wine. They represented about $24 \%$ of respondents (consumption), 15\% (knowledge) and 17\% (confidence).

Consumption, knowledge and confidence were directly correlated and, therefore, individuals who are highly involved with wine tend to be fairly confident in detecting quality differences, know a great deal about wine and consume more wine. The slightly lower correlation between consumption and confidence, compared to that between consumption and knowledge or between knowledge and skill is consistent with the normal progression in wine involvement, from initial consumption to seeking/acquiring knowledge and subsequently developing a palate.

\section{INSERT TABLE 3}

\subsection{Impact of Purchase Goal on Value Indicators}

For each purchase goal, the importance of conspicuous and inconspicuous value indicators was measured using a five-point Likert scale (Table 4). Most average ratings are greater than three, indicating (agreement) that most factors are important in each type of purchase situation.

For purchases intended for home consumption, the most important indicator was the varietal, followed by price and country of origin. The least important indicator for this goal was 
marketing/advertising/promotions. For purchases in a restaurant/bar, the most important indicator was varietal, followed by price. The least important indicator for such purchases was the packaging, followed by marketing, newspaper reviews and in-store promotions. When purchasing wine as a gift, respondents indicated that the most important indicators were varietal, brand and price. The least important indicators were marketing and newspaper reviews.

When purchasing wine at a restaurant/bar, the choice of wine is usually based on the recommendations of staff or limited to selection from a wine list that might only convey brand name, varietal and price. Such purchase behaviour explains why recommendations from restaurant/bar staff or bottle shop employees were significantly more important, but most other indicators became significantly less important in this goal. Recommendations from friends and family were less important for purchases in a bar/restaurant, likely due to those people not being present at the time of purchase (or present but lacking knowledge), while staff are on the spot with reliable information about the listed wines (and possibly a keen motivation to sell) (Table 4).

When purchasing wine as a gift, the importance of brand name and packaging rose significantly. Gift selections may reflect the purchaser's use of the brand as a reliable sign of quality and the packaging to convey a favourable first impression to the recipient. Recommendations from friends, family and colleagues were all significantly less important for the goal of gift-giving - perhaps a risk minimisation strategy for the purchaser. Although varietal is the most important indicator for purchases in all three goals, it is significantly less important in the gift-giving goal. This could reflect uncertainty about the recipient's varietal preference, so the purchaser relies less on varietal and uses brand, packaging and price to ensure the wine is likely to be good quality and well received.

\section{INSERT TABLE 4}

Regression results show the association between purchase goal and value indicators, controlling for respondents' age, gender and product involvement. The coefficients for purchase goal show the change in rating points from home consumption to another goal: thus, purchase goals matter (Table 5). Relative to purchasing for home consumption, when purchasing wine as a gift, the packaging (0.8 points) and brand (0.3) assume greater 
importance, and the varietal (0.4) and recommendations from friends (-0.4), family (-0.3) and work colleagues (-0.2) are of less importance. In purchasing wine for public consumption in a restaurant, recommendations from staff (0.3) increase in importance, but packaging (-0.6), availability (-0.3), marketing (-0.2), in-store promotions (-0.2), recommendations (from friends (-0.2), family (-0.2) wine professionals (-0.3)), and newspaper reviews $(-0.2)$, all become less important. However, the importance of price and country of origin does not vary significantly with each purchase goal.

The importance of some indicators differs according to the characteristics of respondents. Grape variety, price, availability, brand, marketing, in-store promotion, packaging and recommendations from friends, family and work colleagues were significantly more important for females than for males. Marketing, packaging and recommendations were significantly less important to respondents aged 25 or over; while price and in-store promotions are significantly less important for 35-44 year olds. Country of origin is (marginally) more important for 45-54 year olds.

Differences in wine involvement are associated with variations in the importance of some indicators. In particular, the more wine that is consumed, the less important are country of origin, brand and recommendations from friends, family and work colleagues for the purchasing decision, regardless of purchase goal. A greater knowledge of wine is associated with a greater importance of varietal, country of origin and brand, but a lesser importance of availability and recommendations from family. Higher confidence in 'assessing wine quality and detecting differences' is associated with a higher importance of availability, brand and recommendations from family and wine professionals, but a lower importance of in-store promotions and recommendations from staff.

\section{INSERT TABLE 5}

\subsection{Wine label analysis}

The second part of the study examines how characteristics of the wine, as presented on the label, and individuals' characteristics, are associated with symbolic/experiential perceptions. Such findings could apply to corporate communication and marketing strategy. Upon viewing the label (see Figure 2), respondents rated each of the 15 wines according to experiential aspects (perceived taste, quality and value) and symbolic aspects (conferring status, 
exclusivity) ${ }^{1}$. Higher scores on the seven-point Likert scales indicate stronger agreement and, in some sense, a 'better' opinion of the particular aspect of the wine.

Average ratings on the three experiential characteristics are all above 4, indicating all of the wines tended to be considered tasty, high quality and value for money (Table 6). Wine 4 was considered the most tasty (5.2) and highest quality (5.3) but not the best value for money (4.5), perhaps reflecting perceptions of a very high price based on the ' 100 years old' tag (or the $\$ 1000$ price tag, for those in the know). Wines 5 and 14 tended to be rated lowest regarding perceptions of taste (4.5/4.6), quality (4.4/4.5) and value (4.3 for wine 5 and 4.2 for wine 14). Apart from wines 4, 8 and 11, all wines tended to rate better on perceptions of taste than quality perceptions (perhaps reflecting a greater tendency of respondents to use the neutral center category for quality than for taste, as taste is personal and more likely to be known with some certainty).

The symbolic aspects of the wines were status and exclusivity. Three wines rated lower than four on average for status (indicating the wine did not confer high status) and five wines rated lower than four on average for exclusivity. Again, wine 4 was rated the (relative) best and wine 14 (among) the worst. Wine 3 was least likely to confer exclusivity (3.6). Only wine 4 rated better on exclusivity than on status (although this might be tied to higher use of the neutral category).

\section{INSERT TABLE 6}

Several statistically significant overall (regression) results are worthy of note (Table 7). Females tend to rate all five aspects of the wines as 'better' than the males' ranking, 25-34 year olds tended to rate wines 'worse' on all five aspects, and respondents who believed they know more about wine than their friends and family tended to rate wines 'better'. This interpretation is likely to reflect confidence rather than absolute knowledge, or perhaps familiarity with the general terminology surrounding wine rather than genuinely expert knowledge based on experience.

Consumers who felt more able to detect differences in quality between different brands of wine rated the wines significantly lower on all five aspects of the wine. Perhaps individuals

\footnotetext{
${ }^{1}$ Viewing the label does not rule out knowing about the wine from prior experience or elsewhere.
} 
with such skills appreciate wine as a consumption item rather than a reflection of their social standing, or those without such skills are 'duped' by something in the appearance of the labels.

Consuming more wine compared to friends and family is associated with rating the wines significantly 'worse' on value, taste and quality. However, there is no significant association with the other symbolic and experiential attributes.

Wines priced at $\$ 15$ or more rated significantly higher in status and exclusivity than those priced under $\$ 15$ (the low price group). However, only wines priced at $\$ 30$ or more (the luxury price range) rated significantly higher than wines priced under $\$ 15$ regarding perceptions of taste and quality.

Previous research has found that market success is substantially determined by the design of labels; the product information contained on the label has an effect on the subsequent hedonic taste rate (Gmuer et al., 2015). However, knowledge of the influence of wine labels requires further study; it is the starting point, perhaps, for understanding consumption behaviours, and necessary, as long-term product demand depends on repurchasing. Repurchasing behaviour is determined by different factors, including post-consumption evaluation (Blackwell et al., 2006).

This research suggests the need for qualified information, even additional information on the labels, to aid consumers and prospects as the purchase goal potential of the wine. For example, labels which included terms that distinguished the wine as 'better' than that usually produced (such as varietal) - appears to significantly improve ratings on quality and value, when all else is equal. This type of information could be perceived as indicating a better product, even at the same price. However, there was no significant association between the presence of such indicators and ratings on perceptions of taste, status or exclusivity.

Merlot was chosen as the varietal reference category, with coefficients for other varietals indicating differences in the rating for each symbolic or experiential attribute. Every other varietal for which estimates could be identified was considered significantly less likely to confer high status on the drinker and to be significantly less exclusive than the Merlot, all else equal. For perceptions of taste and quality, all other red wines were rated significantly worse than the Merlot. Only two white wines, Chardonnay and Verdelho, showed a significant difference from the Merlot (indicating the Merlot was superior in taste and quality). However, with only one Merlot, two Chardonnays and one Verdelho among the 
labels, this difference could represent an (unidentified) interaction between these varietals and their respective regions. There was some evidence that two varietals (Shiraz and Sauvignon Blanc) were perceived as better value than Merlot.

Regional effects were estimated for the Barossa, Hunter Valley and Margaret River (all in Australia), relative to the Marlborough region of New Zealand. Labels from the Australian regions were rated significantly better on status and exclusivity compared to labels associated with Marlborough. This result could reflect longstanding traditions and reputations of particular grape-growing areas in Australia relative to the newer, yet premium branded New Zealand wines. In effect, New Zealand wines are potentially not viewed by region but rather as a product of the country. This is an opportunity for New Zealand wines to focus more on selling the country rather than regions. Also, the New Zealand wine labels tended to prominently feature the region rather than the country (and in some cases it is difficult to make out the country of origin at all); this is another potential avenue for future marketing efforts to explore.

There was limited evidence of wines from the Hunter Valley and Margaret River rating better than Marlborough wines on taste and quality. However, ratings of wines from the Barossa Valley were not significantly different from those of Marlborough wines. All else equal, there was no significant difference in the value ratings between the regions.

\section{INSERT TABLE 7}

\section{Conclusions, Limitations and Future Directions}

Purchase goal does affect the importance of product value indicators in the decision-making process and suggests additional considerations for marketing practitioners to link marketing efforts to potential customers making a purchase decision, Hypothesis 1 is supported. Marketers need to align corporate communications and marketing efforts for their chosen purchase goal strategy (e.g. Yellowglen's Always Sparkling tagline and the focus on celebrations and festivities in its advertising). Conspicuous indicators that suggest higher value are more important when the purchase decision is being made for a gift, rather than home consumption. 
In contrast, when the purchaser is also the consumer, less conspicuous indicators, such as referrals, become more important. This preference for referrals for home consumption could be explained by the more personal source, a degree of message personalisation impossible to achieve with conspicuous indicators, and the willingness to risk a negative outcome in private. A marketing effort in this category could feature a campaign which applauds 'risky' behaviours, such as the willingness to try new flavours or experimenting, (perhaps capitalising on desires to be home chefs and cuisine creators) and leverages the word of mouth potential as opinion leaders discover new products and refer (with the inherent benefits of leadership and positive psychological outcomes (Hurling et al., 2015)).

Gift purchasers were risk averse and needed a clear signal that the present was something to be valued or admired (increasing positive affect (Linley et al., 2009)) . These findings suggest the use of value indicators to be contextually driven with the resulting implications for marketing regarding contextualising communication and branding messages. For example, marketing strategy could expand consumption contexts in advertisements to showcase the product as a well-received gift signifying, for example, uniqueness or collector status.

Finally, further research could consider the role of price in concert with the other indicators. In such research, price would be considered a stable indicator, reflecting a binding limit on the purchase within a consumer's budget. Other factors could then be examined in terms of choice selections between wines based on advice and preferences. This would be consistent with a two-stage decision-making process in which the purchaser first allocates a budget for the item and then uses other indicators to select from available alternatives.

Research limitations include the potential for bias inherent in a snowball sample and in selfselection and self-reporting behaviours. The study does not take into consideration non-wine drinkers (who may purchase wine as a gift) or teetotallers. The nature of public consumption was not identified, and there could be differences between dining out for work, (a serious work event compared with an end of year party) and a social event (friend's get-together) or themed celebration (wedding), or between selection for a Bring-Your-Own (BYO) restaurant and from a licensed restaurant's wine list.

Additional limitations arise from the focus on Australian consumers purchasing Australian or New Zealand wine. Future research could focus on a greater range of demographic considerations and include all or multiple countries from both old and new world wine 
producers. Further research could also consider purchase goal and indicator value differences between ethnic groups.

Future research could consider triangulation of psychological factors (e.g. novice vs. experienced consumers, planned behaviour and consumption goals) (Curhan et al., 2015) and purchase goals (including multiple purchase situations) with sensory processes during the hedonic post-consumption evaluation (e.g. Gmuer et al., 2015). Further research could also compare this triangulation with the degree of complexity. Finally, although the results can provide information to marketers on the characteristics that could be emphasised, such advertising would need to comply with existing advertising and labeling regulations.

Notwithstanding these limitations, the clear advantage of this study is the identification that purchase goal does change the value of consumption indicators. This study not only suggests purchase goals impact on value indicators in meaningful, measurable ways but also suggests clear marketing implications for varying product purchase situations in commercials, changing setting locations in advertising, providing rewards for new purchase trial and giving opinion leaders reasons to refer. 
References

AWBR 2005. Analyzing the US retail wine market using price and consumer segmentation models.

AZAR, D., WHITE, V., BLAND, S., LIVINGSTON, M., ROOM, R., CHIKRITZHS, T., DURKIN, S., GILMORE, W. \& WAKEFIELD, M. 2014. 'Something's Brewing': the changing trends in alcohol coverage in Australian newspapers 2000-2011. Alcohol and Alcoholism, 49, 336-342.

BELK, R. W. 1988. Possessions and the extended self. Journal of consumer research, 15, 139-168.

BLACKWELL, R. D., MINIARD, P. W. \& ENGEL, J. F. 2006. Consumer Behavior, Mason (Ohio) Thomson/South-Western.

BLIGH, G., MOUNTER, S., FLEMING, E., GRIFFITH, G. \& VILLANO, R. 2015. The Australian wine industry at the crossroads: A comparison of performance across major wine-exporting countries in 2000. Australasian Journal of Regional Studies, 21, 3-25.

BRUCKS, M., ZEITHAML, V. A. \& NAYLOR, G. 2000. Price and Brand Name As Indicators of Quality Dimensions for Consumer Durables. Journal of the Academy of Marketing Science, 28, 359-374.

BRUWER, J., LESSCHAEVE, I., GRAY, D. \& SOTTINI, V. A. Regional Brand Perception by Wine Tourists within a Winescape Framework. Academy of Wine Business Research, 2013. AWBR.

BRUWER, J., LI, E. \& REID, M. 2002. Segmentation of the Australian wine market using a wine-related lifestyle approach. Journal of Wine Research, 13, 217-242.

BUES, M., STEINER, M., STAFFLAGE, M. \& KRAFFT, M. 2017. How Mobile In-Store Advertising Influences Purchase Intention: Value Drivers and Mediating Effects from a Consumer Perspective. Psychology \& Marketing, 34, 157-174.

CELHAY, F. \& PASSEBOIS, J. 2011. Wine labelling: is it time to break with tradition? A study of the moderating role of perceived risk. International Journal of Wine Business Research, 23, 318-337.

CHARTERS, S. \& PETTIGREW, S. 2006. Product involvement and the evaluation of wine quality. Qualitative Market Research: An International Journal, 9, 181-193.

CHARTERS, S. \& PETTIGREW, S. 2008. Why Do People Drink Wine? A ConsumerFocused Exploration. Journal of Food Products Marketing, 14, 13-32.

CHAUDHURI, H. R. \& MAJUMDAR, S. 2006. Of Diamonds and desires: understanding conspicuous consumption from a contemporary marketing perspective. Academy of Marketing Science Review, 11.

CHRYSOCHOU, P. \& JØRGENSEN, J. B. Danish Consumer Preferences for Wine and the Impact of Involvement. 9th Academy of Wine Business Research Conference, 2016.

CLARKE, O. 2002. Oz Clarke's new wine atlas: Wines and wine regions of the world, Houghton Mifflin Harcourt.

CORDUAS, M., CINQUANTA, L. \& IEVOLI, C. 2013. The importance of wine attributes for purchase decisions: a study of Italian consumers' perception. Food Quality and Preference, 28, 407-418.

CORSI, A. M., MUELLER, S. \& LOCKSHIN, L. 2012. Let's see what they have... what consumers look for in a restaurant wine list. Cornell Hospitality Quarterly, 53, 110121.

CURHAN, S. G., EAVEY, R., WANG, M., STAMPFER, M. J. \& CURHAN, G. C. 2015. Prospective study of alcohol consumption and self-reported hearing loss in women. Alcohol, 49, 71-77. 
DE VISSER, R., O. \& MCDONNELL, E., J. 2012. 'That's OK. He's a guy': A mixedmethods study of gender double-standards for alcohol use. Psychology \& Health, 27, 618-639.

DIMSON, E., ROUSSEAU, P. L. \& SPAENJERS, C. 2015. The price of wine. Journal of Financial Economics, 118, 431-449.

DUNPHY, R. \& LOCKSHIN, L. 1998. A contemporary perspective of the Australian wine show system as a marketing tool. Journal of Wine Research, 9, 107-129.

EDWARDS, F. \& SPAWTON, T. 1990. Pricing in the Australian Wine Industry. European Journal of Marketing, 24, 11-17.

FELZENSZTEIN, C., STRINGER, C., BENSON-REA, M. \& FREEMAN, S. 2014. International marketing strategies in industrial clusters: Insights from the Southern Hemisphere. Journal of Business Research, 67, 837-846.

FESTA, G., CUOMO, M. T., METALLO, G. \& FESTA, A. 2016. The (r) evolution of wine marketing mix: From the 4Ps to the 4Es. Journal of Business Research, 69, 15501555.

FIEBIG, D. G. 2001. Seemingly unrelated regression. A companion to theoretical econometrics, 101-121.

GINON, E., ARES, G., ISSANCHOU, S., DOS SANTOS LABOISSIÈRE, L. H. E. \& DELIZA, R. 2014. Identifying motives underlying wine purchase decisions: Results from an exploratory free listing task with Burgundy wine consumers. Food research international, 62, 860-867.

GMUER, A., SIEGRIST, M. \& DOHLE, S. 2015. Does wine label processing fluency influence wine hedonics? Food Quality and Preference, 44, 12-16.

GOLDMAN, D. 2012. Wine Tasting Through Typography. California: California Polytechnic State University.

GROVES, R., CHARTERS, S. \& REYNOLDS, C. 2000. Imbibing, inscribing, integrating and imparting: A taxonomy of wine consumption practices. Journal of Wine Research, 11, 209-222.

GUY, K. M. 2007. When champagne became French: Wine and the making of a national identity.

HALONEN, J. I., KIVIMÄKI, M., PENTTI, J., VIRTANEN, M., SUBRAMANIAN, S., KAWACHI, I. \& VAHTERA, J. 2014. Association of the Availability of Beer, Wine, and Liquor Outlets with Beverage-Specific Alcohol Consumption: A Cohort Study. Alcoholism: Clinical and Experimental Research, 38, 1086-1093.

HEFFETZ, O. 2011. A Test of Conspicuous Consumption: Visibility and Income Elasticities. Review of Economics and Statistics, 93, 1101-1117.

HOWLAND, P. J. 2014. Social, cultural and economic impacts of wine in New Zeland, Abingdon, Routledge.

HURLING, R., LINLEY, P. A., DOVEY, H., MALTBY, J. \& WILKINSON, J. 2015. Everyday happiness: Gifting and eating as everyday activities that influence general positive affect and discrete positive emotions. International Journal of Wellbeing, 5.

JAEGER, S. R., DANAHER, P. J. \& BRODIE, R. J. 2009. Wine purchase decisions and consumption behaviours: Insights from a probability sample drawn in Auckland. Food Quality and Preference., 20, 312-319.

KEEL, A. L. \& PADGETT, D. 2015. The effects of adjacent competitors and promotion on brand sales. Journal of Consumer Marketing, 32, 43-50.

KELLEY, K., HYDE, J. \& BRUWER, J. 2015. US wine consumer preferences for bottle characteristics, back label extrinsic cues and wine composition: A conjoint analysis. Asia Pacific Journal of Marketing and Logistics, 27, 516-534. 
KOCH, J., MARTIN, A. \& NASH, R. 2013. Overview of perceptions of German wine tourism from the winery perspective. International Journal of Wine Business Research, 25, 50-74.

KOFI, C. K., HURST, E. \& ROUSSANOV, N. 2009. Conspicuous Consumption and Race. The Quarterly Journal of Economics, 124, 425-467.

KRASKER, W. S. 1979. Rate of Return to Storing Wines. Journal of Political Economy 87, 1363-1367.

LECAT, B., LE FUR, E., OUTREVILlE, J. F., BRUWER, J. \& BRUWER, J. 2016. Perceived risk and the willingness to buy and pay for" corked" bottles of wine. International Journal of Wine Business Research, 28.

LINLEY, P. A., MALTBY, J., WOOD, A. M., OSBORNE, G. \& HURLING, R. 2009. Measuring happiness: The higher order factor structure of subjective and psychological well-being measures. Personality and Individual Differences, 47, 878884.

LOCKSHIN, L. \& CORSI, A. 2012. Consumer behaviour for wine 2.0: A review since 2003 and future directions. Wine Economics and Policy, 1, 2-33.

LOCKSHIN, L., JARVIS, W., D'HAUTEVILlE, F. \& PERROUTY, J.-P. 2006. Using simulations from discrete choice experiments to measure consumer sensitivity to brand, region, price, and awards in wine choice. Food Quality and Preference, 17, 166-178.

LOUVIERE, J. J., HENSHER, D. A. \& SWAIT, J. D. 2000. Stated Choice Methods: Analysis and Application, Cambridge: United Kingdom, Cambridge University Press.

MASSET, P., WEISSKOPF, J. P., FAYE, B. \& LE FUR, E. 2015. Red obsession: the ascent of fine wine in China.

MAYNARD, L. J. \& DAVIDSON, K. 2009. Consumer-Level Determinants of Wine Purchases in Canadian Restaurants. Journal of Wine Economics,, 4, 10-24.

MCCUTCHEON, E., BRUWER, J. \& LI, E. 2009. Region of origin and its importance among choice factors in the wine-buying decision making of consumers. International Journal of Wine Business Research, 21, 212-234.

MOREY, R. C., SPARKS, B. A. \& WILKINS, H. C. 2002. Purchase situation modelling in wine selection: an evaluation of factors in an Australian context. International Journal of Wine Marketing, 14, 41-64.

MORRISON, A. \& RABELLOTTI, R. 2014. Gradual Catch Up and Enduring Leadership in the Global Wine Industry [Online]. Available: http://www.wineeconomics.org/aawe/wp-content/uploads/2014/02/AAWE WP148.pdf [Accessed 20 October 2014].

MOULARD, J., BABIN, B. J. \& GRIFFIN, M. 2015. How aspects of a wine's place affect consumers' authenticity perceptions and purchase intentions: The role of country of origin and technical terroir. International Journal of Wine Business Research, 27, 6178.

NEW ZEALAND WINE 2014. New Zealand Winegrowers annual report. New Zealand.

PEREMANS, K. \& VAN AELST, S. 2016. Fast and robust bootstrap in seemingly unrelated regression models.

RATNER, R. K. \& KAHN, B. E. 2001. Private vs. public consumption: The impact of impression management on variety seeking. Citeseer.

RATNER, R. K. \& KAHN, B. E. 2002. The impact of private versus public consumption on variety-seeking behavior. Journal of Consumer Research, 29, 246-257.

RICHINS, M. L. 1994a. Special Possessions and the Expression of Material Values. Journal of Consumer Research, 21, 522-533. 
RICHINS, M. L. 1994b. Valuing Things: The Public and Private Meanings of Possessions. Journal of Consumer Research, 21, 504-521.

RITCHIE, C. 2007. Beyond drinking: the role of wine in the life of the UK consumer. International Journal of Consumer Studies, 31, 534-540.

ROWLEY, M. 2016. Export markets: US consumers continue to rely on varietal cues for their purchase decisions. Wine \& Viticulture Journal, 31, 70.

SCHONLAU, M., FRICKER, R. \& ELLIOTT, M. 2002. Conducting Research Surveys Via $E$-Mail and the Web, CA, RAND.

SILVA, A. P., JAGER, G., VAN ZYL, H., VOSS, H.-P., PINTADO, M., HOGG, T. \& DE GRAAF, C. 2015. Cheers, Proost, Saúde: Cultural, contextual and psychological factors of wine and beer consumption in Portugal and in the Netherlands. Critical reviews in food science and nutrition, 00-00.

SMEETS, L. 2004. A perception of the Dutch and German consumer. Honours, University of Maastricht.

SZOLNOKI, G. \& HOFFMANN, D. 2014. Consumer segmentation based on usage of sales channels in the German wine market. International Journal of Wine Business Research, 26, 27-44.

TATZEL, M. 2002. Money Worlds' and Well-Being: An Integration of Money Dispositions, Materialism and Price-Related Behavior. Journal of Economic Psychology, 23, 103126.

THOMAS, A. \& PICKERING, G. 2003. The importance of wine label information. International Journal of Wine Marketing, 15, 58-74.

TRADE DATA \& ANALYSIS 2013. World Vineyard, Grape and Wine Report California: TDA.

VARGO, S. L. \& LUSCH, R. F. 2008. Evolving to a new dominant logic for marketing. Journal of Marketing, 68, 1-17.

VEBLEN, T. 2007. The theory of the leisure class, Oxford, Oxford University Press.

WELLS, K. 2007. Australia's wine industry. In: LTD, B. B. D. C. P. (ed.). Canberra: Australian Government.

WIEDMANN, K.-P., BEHRENS, S., HENNIGS, N. \& KLARMANN, C. 2016. What is the Perceived Value of Wine? A Cross-Generation Study of Consumer Wine Perception and Consumption Behavior. In: C., C. \& J., M. (eds.) Looking Forward, Looking Back: Drawing on the Past to Shape the Future of Marketing: Proceedings of the Academy of Marketing Science. Cham: Springer.

WILLIAMS, A. \& ATWAL, G. 2013. The hedonistic consumption of luxury and iconic wines. In: VERLAG, G. (ed.) Luxury marketing.

WINE FOLLY. 2016. Reality of Wine Prices (What You Get For What You Spend) [Online]. Wine News \& Entertainment. Available: http://winefolly.com/update/reality-of-wineprices-what-you-get-for-what-you-spend/ [Accessed February 23 2017].

WOODSIDE, A. G. 2012. Economic psychology and fashion marketing theory appraising Veblen's theory of conspicuous consumption. Journal of Global Fashion Marketing, 3, 55-60.

ZEITHAML, V. 1998. Consumer perceptions of price, quality and value: a means-end model and synthesis of evidence. Journal of Marketing, 52, 2-22.

ZELLNER, A. 1962. Estimators for Seemingly Unrelated Regression and tests of aggregation bias. Journal of the American Statistical Association, 57, 500-509.

ZELLNER, A. 1963. Estimators for seemingly unrelated regression equations: Some exact finite sample results. Journal of the American Statistical Association, 58, 977-992. 


\section{Appendix A: Tables and Figures}

\section{Figure 1: Conceptual Framework Underpinning Wine Purchases}

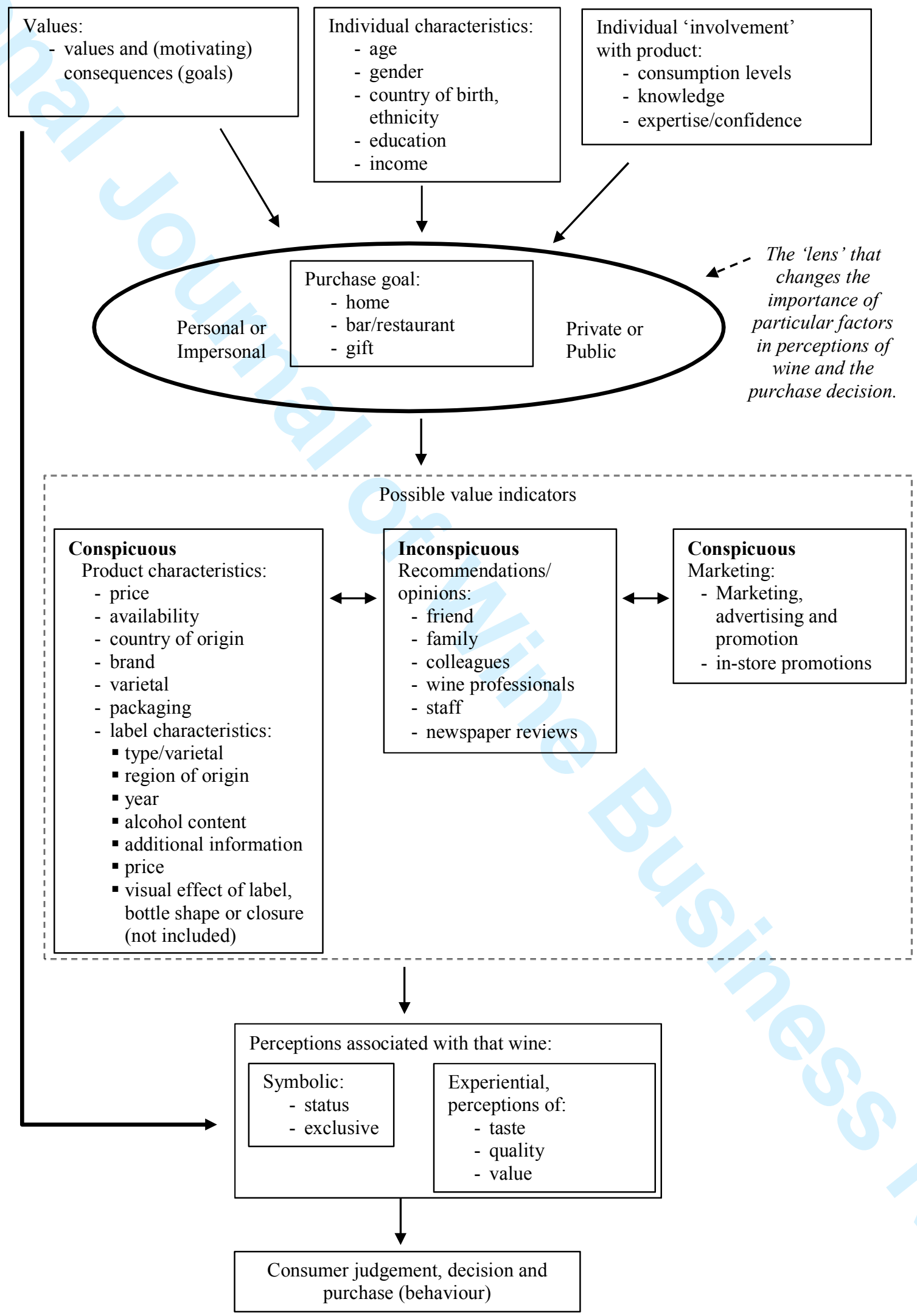


Table 1: Vineyard labels comprising the sample

\begin{tabular}{|c|c|c|c|c|c|c|c|c|}
\hline $\begin{array}{l}\text { Label } \\
\text { no. }\end{array}$ & Country & Region & Type & Varietal & Year & $\begin{array}{l}\text { Indicative } \\
\text { price }^{\mathbf{a b}}\end{array}$ & $\begin{array}{l}\text { Alcohol } \\
\text { content } \\
(\%)\end{array}$ & $\begin{array}{l}\text { Additional } \\
\text { label } \\
\text { information }\end{array}$ \\
\hline 1 & Australia & Barossa Valley & White & Semillon & na & $\$ 10-<15$ & 11.5 & \\
\hline 2 & Australiab & Barossa Valley $\mathbf{b}$ & Red & Shiraz & na & $\$ 10-<15$ & na & Vintage,reserve \\
\hline 3 & Australia & Barossa Valley & Red & Cabernet Sauvignon & 2004 & $\$ 10-<15^{\mathbf{d}}$ & 13.5 & Half bottle \\
\hline & & & Fortifie & & & & & \\
\hline 4 & Australiab & Barossa Valleyb & $\mathrm{d}$ & Tawny & na & $\$ 1,000$ & na & 100 year old \\
\hline 5 & Australia & Hunter Valley & White & Verdelho & 2003 & $\$ 15-<20$ & na & Members \\
\hline 6 & Australia & Hunter Valley & Red & Shiraz & na & $\$ 15-<20$ & 14 & Cellar release \\
\hline 7 & Australia & Margaret River & Red & Merlot & 2001 & $\$ 10-<15$ & 14 & \\
\hline 8 & Australiab & Margaret River & Red & Red blend $\mathbf{b}$ & 2001 & $\$ 40$ & na & \\
\hline 9 & Australia & Margaret River & Red & Cabernet Sauvignon & 2002 & $\$ 50$ & na & \\
\hline 10 & Australiab & Yarra Valley & White & Chardonnay & na & $\$ 25-<30$ & na & Estate grown \\
\hline 11 & New Zealand & Hawke’s Bay & Red & Merlot Cabernet & 1998 & $\$ 15-<20$ & 13.5 & Vintage \\
\hline 12 & New Zealand ${ }^{\mathbf{b}}$ & Marlborough & White & Sauvignon Blanc & 2001 & $\$ 15-<20$ & 13.5 & \\
\hline 13 & New Zealand ${ }^{\mathbf{b}}$ & Marlborough b & White & Sauvignon Blanc & 2001 & $\$ 30$ & na & \\
\hline 14 & New Zealand & Marlborough & White & Chardonnay & 2004 & $\$ 15$ & 13.5 & \\
\hline 15 & New Zealand & Marlborough & Red & Pinot Noir & na & $\$ 20-<30$ & na & \\
\hline
\end{tabular}

a Likely retail price (\$AUD) at the time of the survey. b Not displayed on the label.

c Labelled as South Australia. $\mathbf{d}$ Full bottle price. na Not available. 
Figure 2: Wine labels

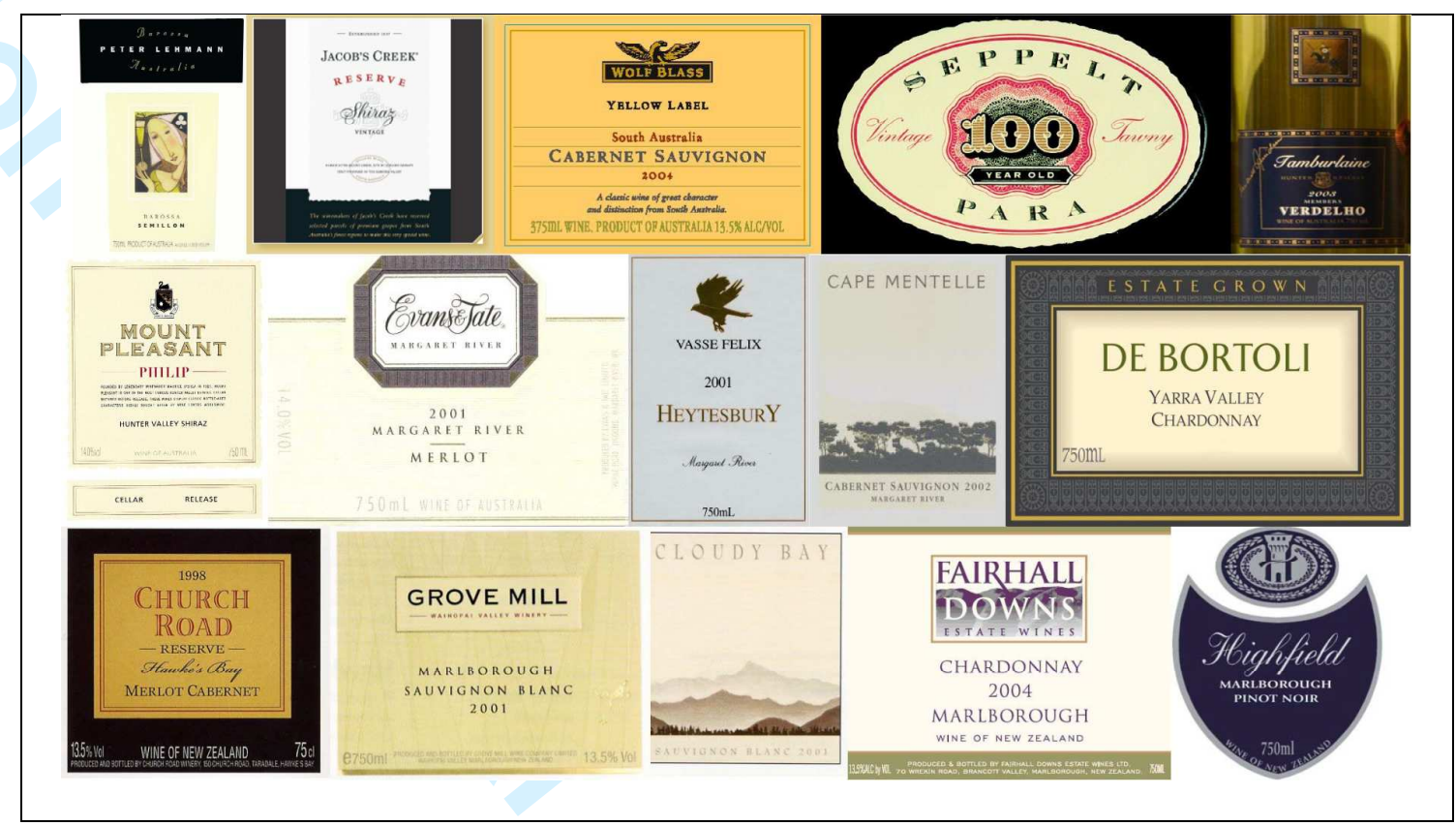

http://mc.manuscriptcentral.com/ijwbr 
Table 2: Respondent characteristics (estimation sample $\mathbf{n = 2 4 9}$ )

\begin{tabular}{|c|c|c|}
\hline Characteristic & No. & $\%$ \\
\hline \multicolumn{3}{|l|}{ Gender: } \\
\hline Male & 117 & 47.0 \\
\hline Female & 132 & 53.0 \\
\hline \multicolumn{3}{|l|}{ Age: } \\
\hline $18-24$ years & 18 & 7.2 \\
\hline $25-34$ years & 58 & 23.3 \\
\hline $35-44$ years & 62 & 24.9 \\
\hline $45-54$ years & 68 & 27.3 \\
\hline $55+$ years & 43 & 17.3 \\
\hline \multicolumn{3}{|l|}{ Country of birth: } \\
\hline Australia & 190 & 63.8 \\
\hline United Kingdom & 33 & 11.1 \\
\hline New Zealand & 23 & 7.7 \\
\hline Other & 52 & 17.4 \\
\hline Total & 298 & 100.0 \\
\hline \multicolumn{3}{|l|}{ Country of current residence: } \\
\hline Australia & 243 & 81.5 \\
\hline New Zealand & 20 & 6.7 \\
\hline United Kingdom & 17 & 5.7 \\
\hline Other & 16 & 5.4 \\
\hline Missing & 2 & 0.7 \\
\hline Total & 298 & 100.0 \\
\hline \multicolumn{3}{|l|}{ Ethnic group: } \\
\hline Anglo-Saxon & 261 & 87.6 \\
\hline Prefer not to say & 9 & 3.0 \\
\hline Mediterranean or Hispanic person & 8 & 2.7 \\
\hline Chinese, Japanese, or South-East Asian person & 7 & 2.3 \\
\hline Indian, Pakistani, Bangladeshi, or any other Asian person & 5 & 1.7 \\
\hline African/Caribbean person & 1 & 0.3 \\
\hline Arabic, Egyptian or Maghreb person & 1 & 0.3 \\
\hline Missing & 6 & 2.0 \\
\hline Total & 298 & 100.0 \\
\hline
\end{tabular}


Table 3: Wine consumption and knowledge of respondents - correlation matrix

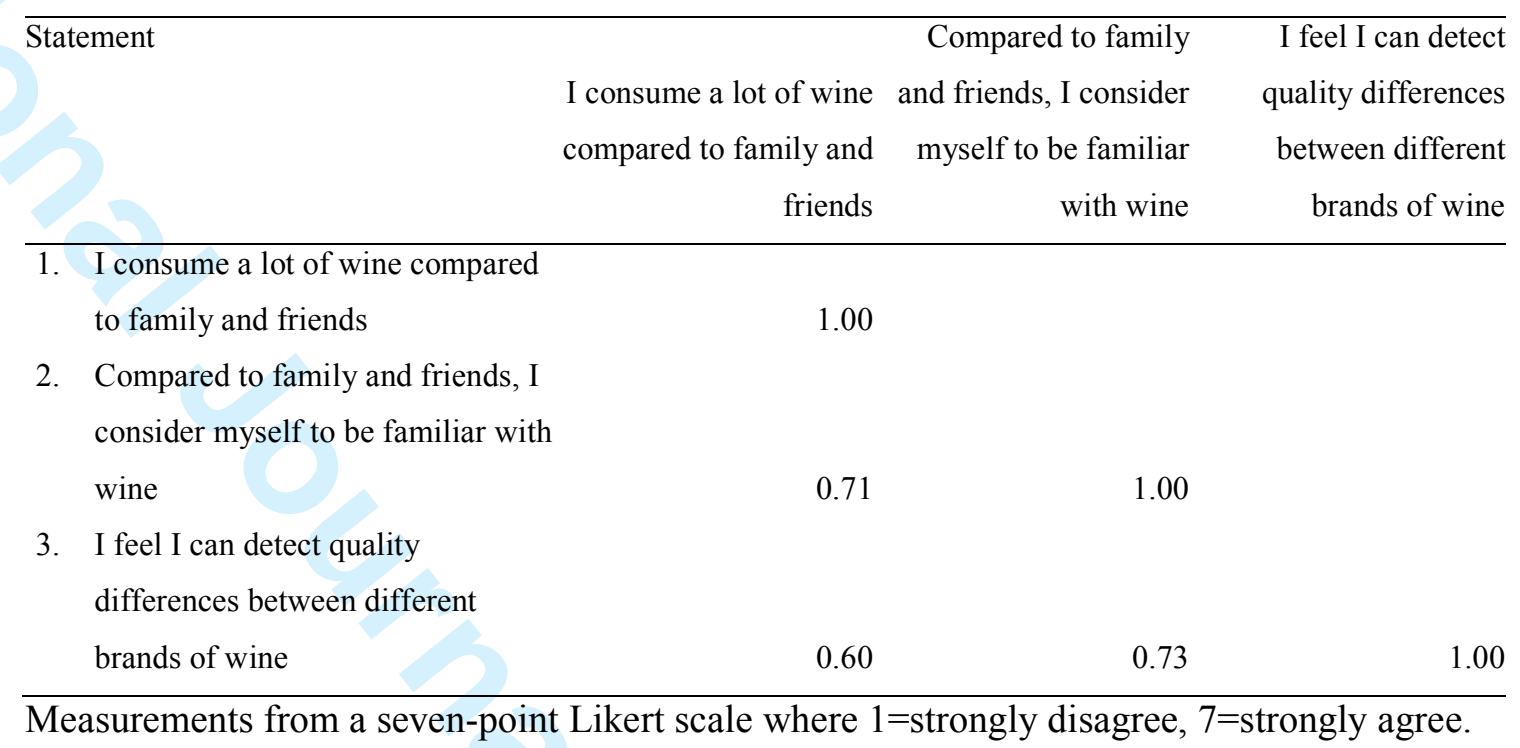


Table 4: Mean importance of value indicators by purchasing goal $(n=249)$

\begin{tabular}{lccr}
\hline & \multicolumn{3}{c}{ Purchasing goal } \\
\cline { 2 - 4 } Value indicator & Home & Restaurant/Bar & Gift \\
\hline Price & 4.016 & 4.133 & 3.980 \\
Availability & 3.418 & 3.205 & 3.510 \\
Country of origin & 3.948 & 3.843 & 3.964 \\
Brand name & 3.751 & 3.831 & 4.060 \\
Varietal (type) & 4.410 & 4.317 & 4.072 \\
Packaging & 3.157 & 2.562 & 3.928 \\
Recommendation from: & & & \\
friend & 3.876 & 3.695 & 3.510 \\
family & 3.667 & 3.538 & 3.422 \\
colleague & 3.614 & 3.534 & 3.398 \\
wine professional & 3.739 & 3.542 & 3.671 \\
bar/bottle shop employee & 3.181 & 3.526 & 3.161 \\
Review in a newspaper & 3.153 & 2.892 & 2.968 \\
Marketing/Advertising/Promotions & 2.847 & 2.727 & 2.956 \\
In-store promotions & 3.137 & 2.960 & 3.092
\end{tabular}

Measurements from a five-point Likert scale where $1=$ strongly disagree, $5=$ strongly agree. 
Table 5: Results on value indicators - effect of goal

\begin{tabular}{|c|c|c|c|c|c|c|c|c|c|c|c|c|c|c|c|c|c|c|c|c|}
\hline \multirow[b]{3}{*}{ Variable } & \multicolumn{20}{|c|}{ Value indicator equation } \\
\hline & \multicolumn{3}{|c|}{ Varietals } & \multicolumn{3}{|l|}{ Price } & \multicolumn{3}{|c|}{ Availability } & \multicolumn{3}{|c|}{ Country of origin } & \multicolumn{3}{|l|}{ Brand } & \multicolumn{3}{|c|}{ Marketing } & \multicolumn{2}{|l|}{ In-store promo } \\
\hline & Coef. & SE & & Coef. & SE & & Coef. & SE & & Coef. & SE & & Coef. & SE & & Coef. & SE & & Coef. SE & \\
\hline Female & 0.181 & 0.065 & $* * *$ & 0.158 & 0.071 & $* *$ & 0.198 & 0.081 & $* *$ & 0.121 & 0.076 & & 0.173 & 0.065 & $* * *$ & 0.147 & 0.076 & $*$ & $0.255 \quad 0.080$ & $* * *$ \\
\hline \multicolumn{21}{|l|}{ Age: } \\
\hline 25-34 years & -0.128 & 0.136 & & -0.193 & 0.148 & & -0.258 & 0.169 & & 0.071 & 0.159 & & 0.027 & 0.136 & & -0.410 & 0.157 & $* * *$ & -0.1930 .166 & \\
\hline $35-44$ years & -0.148 & 0.135 & & -0.353 & 0.147 & $* *$ & -0.216 & 0.168 & & -0.034 & 0.157 & & -0.051 & 0.135 & & -0.382 & 0.156 & $* *$ & -0.3430 .164 & $* *$ \\
\hline $45-54$ years & -0.088 & 0.134 & & -0.130 & 0.146 & & -0.164 & 0.167 & & 0.265 & 0.157 & $*$ & -0.022 & 0.134 & & -0.282 & 0.155 & $*$ & -0.1140 .164 & \\
\hline $55+$ years & -0.163 & 0.141 & & -0.121 & 0.154 & & 0.024 & 0.175 & & 0.157 & 0.165 & & -0.025 & 0.141 & & -0.443 & 0.163 & $* * *$ & -0.2800 .172 & \\
\hline Consumption & 0.002 & 0.025 & & 0.004 & 0.027 & & 0.015 & 0.031 & & -0.066 & 0.029 & $* *$ & -0.099 & 0.025 & $* * *$ & -0.012 & 0.029 & & $0.003 \quad 0.030$ & \\
\hline Knowledge & 0.134 & 0.033 & $* * *$ & -0.004 & 0.036 & & -0.077 & 0.041 & $*$ & 0.082 & 0.039 & $* *$ & 0.101 & 0.033 & $* * *$ & 0.001 & 0.038 & & -0.0220 .040 & \\
\hline Detect quality & -0.022 & 0.029 & & 0.018 & 0.032 & & 0.103 & 0.036 & $* * *$ & 0.041 & 0.034 & & 0.060 & 0.029 & $* *$ & -0.033 & 0.033 & & -0.0840 .035 & $* *$ \\
\hline \multicolumn{21}{|l|}{ Goal: } \\
\hline Restaurant & -0.118 & 0.078 & & 0.045 & 0.084 & & -0.263 & 0.096 & $* * *$ & -0.128 & 0.090 & & 0.096 & 0.077 & & -0.165 & 0.090 & $*$ & -0.1990 .094 & $* *$ \\
\hline Gift & -0.364 & 0.077 & $* * *$ & -0.062 & 0.084 & & 0.052 & 0.096 & & 0.019 & 0.090 & & 0.302 & 0.077 & $* * *$ & 0.103 & 0.089 & & -0.0160 .094 & \\
\hline constant & 3.864 & 0.157 & $* * *$ & 4.078 & 0.171 & $* * *$ & 3.278 & 0.195 & $* * *$ & 3.468 & 0.183 & $* * *$ & 3.332 & 0.157 & $* * *$ & 3.335 & 0.182 & $* * *$ & 3.7130 .191 & $* * *$ \\
\hline
\end{tabular}

Dependent variables are measurements from a five-point Likert scale where $1=$ strongly disagree, $5=$ strongly agree. Consumption, knowledge and detecting quality are measurements from a seven-point Likert scale where 1=strongly disagree, $7=$ strongly agree.

* Significant at $0.10 ; * *$ Significant at $0.05 ; * * *$ Significant at 0.01 . 
(Table 5 continued)

\begin{tabular}{|c|c|c|c|c|c|c|c|c|c|c|c|c|c|c|c|c|c|c|c|c|}
\hline \multirow[b]{3}{*}{ Variable } & \multicolumn{20}{|c|}{ Value indicator equation } \\
\hline & \multicolumn{3}{|c|}{ Packaging } & \multicolumn{3}{|l|}{ Friend } & \multicolumn{3}{|l|}{ Family } & \multicolumn{3}{|l|}{ Work } & \multicolumn{3}{|c|}{ Wine Professional } & \multicolumn{2}{|c|}{ Newspaper } & \multicolumn{3}{|c|}{ Bar Staff } \\
\hline & Coef. & $\mathrm{SE}$ & & Coef. & $\mathrm{SE}$ & & Coef. & $\mathrm{SE}$ & & Coef. & SE & & Coef. & SE & & Coef. & SE & & Coef. SE & \\
\hline Female & 0.286 & 0.076 & $* * *$ & 0.249 & 0.072 & $* * *$ & 0.465 & 0.078 & $* * *$ & 0.273 & 0.074 & $* * *$ & 0.041 & 0.077 & & -0.060 & 0.079 & & $\begin{array}{ll}0.086 & 0.073\end{array}$ & \\
\hline \multicolumn{21}{|l|}{ Age: } \\
\hline 25-34 years & -0.300 & 0.159 & $*$ & -0.657 & 0.150 & $* * *$ & -0.638 & 0.163 & $* * *$ & -0.337 & 0.153 & $* *$ & -0.736 & 0.161 & $* * *$ & -0.116 & 0.164 & & -0.4130 .152 & $* * *$ \\
\hline $35-44$ years & -0.586 & 0.157 & $* * *$ & -0.599 & 0.148 & $* * *$ & -0.853 & 0.161 & $* * *$ & -0.377 & 0.152 & $* *$ & -0.796 & 0.159 & $* * *$ & 0.137 & 0.162 & & -0.5260 .151 & $* * *$ \\
\hline $45-54$ years & -0.422 & 0.156 & $* * *$ & -0.710 & 0.148 & $* * *$ & -0.832 & 0.161 & $* * *$ & -0.451 & 0.151 & $* * *$ & -0.817 & 0.159 & $* * *$ & 0.149 & 0.162 & & -0.3930 .150 & $* * *$ \\
\hline $55+$ years & -0.456 & 0.164 & $* * *$ & -0.791 & 0.155 & $* * *$ & -0.927 & 0.169 & $* * *$ & -0.559 & 0.159 & $* * *$ & -0.993 & 0.167 & $* * *$ & 0.157 & 0.170 & & -0.5870 .158 & $* * *$ \\
\hline Consumption & -0.031 & 0.029 & & -0.081 & 0.027 & $* * *$ & -0.060 & 0.030 & $* *$ & -0.097 & 0.028 & $* * *$ & -0.026 & 0.029 & & -0.030 & 0.030 & & -0.0070 .028 & \\
\hline Knowledge & -0.008 & 0.039 & & -0.011 & 0.036 & & -0.167 & 0.040 & $* * *$ & 0.025 & 0.037 & & -0.040 & 0.039 & & 0.041 & 0.040 & & $0.057 \quad 0.037$ & \\
\hline Detect quality & -0.015 & 0.034 & & 0.000 & 0.032 & & 0.144 & 0.035 & $* * *$ & -0.013 & 0.033 & & 0.151 & 0.034 & $* * *$ & 0.046 & 0.035 & & -0.0910 .032 & $* * *$ \\
\hline \multicolumn{21}{|l|}{ Goal: } \\
\hline Bar & -0.597 & 0.090 & $* * *$ & -0.209 & 0.085 & $* *$ & -0.185 & 0.093 & $* *$ & -0.130 & 0.087 & & -0.256 & 0.092 & $* * *$ & -0.234 & 0.093 & $* *$ & $0.291 \quad 0.087$ & $* * *$ \\
\hline Gift & 0.790 & 0.090 & $* * *$ & -0.370 & 0.085 & $* * *$ & -0.281 & 0.092 & $* * *$ & -0.246 & 0.087 & $* * *$ & -0.071 & 0.091 & & -0.131 & 0.093 & & -0.0210 .086 & \\
\hline constant & 3.651 & 0.183 & $* * *$ & 4.797 & 0.173 & $* * *$ & 4.567 & 0.188 & $* * *$ & 4.241 & 0.177 & $* * *$ & 4.012 & 0.186 & $* * *$ & 2.778 & 0.189 & $* * *$ & 3.7990 .176 & $* * *$ \\
\hline
\end{tabular}

Dependent variables are measurements from a five-point Likert scale where $1=$ strongly disagree, 5=strongly agree. Consumption, knowledge and detecting quality are measurements from a seven-point Likert scale where $1=$ strongly disagree, $7=$ strongly agree. 


\section{Page 31 of 34}

International Journal of Wine Business Research

* Significant at $0.10 ; * *$ Significant at $0.05 ; * * *$ Significant at 0.01

http://mc.manuscriptcentral.com/ijwbr 
Table 6: Mean rating of labels by symbolic/experiential perception $(n=249)$

\begin{tabular}{lrrr|rr}
\hline & \multicolumn{3}{c|}{ Symbolic aspect } & \multicolumn{2}{c}{ Experiential aspect } \\
\hline Label no. & Tasty & Quality & Value & Status & Exclusive \\
\hline 1 & 4.75 & 4.65 & 4.53 & 4.06 & 3.72 \\
2 & 4.90 & 4.69 & 4.76 & 3.92 & 3.69 \\
3 & 4.81 & 4.65 & 4.61 & 3.91 & 3.58 \\
4 & 5.24 & 5.33 & 4.49 & 5.10 & 5.22 \\
5 & 4.57 & 4.47 & 4.27 & 4.11 & 4.11 \\
6 & 5.07 & 5.06 & 4.65 & 4.56 & 4.44 \\
7 & 4.96 & 4.95 & 4.56 & 4.43 & 4.20 \\
8 & 4.95 & 5.07 & 4.41 & 4.67 & 4.63 \\
9 & 5.05 & 5.04 & 4.48 & 4.52 & 4.36 \\
10 & 4.79 & 4.69 & 4.56 & 4.13 & 3.92 \\
11 & 4.71 & 5.02 & 4.31 & 4.35 & 4.31 \\
12 & 4.73 & 4.66 & 4.33 & 4.14 & 4.00 \\
13 & 5.02 & 4.86 & 4.45 & 4.36 & 4.01 \\
14 & 4.52 & 4.39 & 4.18 & 3.86 & 3.72 \\
15 & 4.96 & 4.88 & 4.37 & 4.49 & 4.41 \\
\hline
\end{tabular}

Measurements from a seven-point Likert scale where 1=strongly disagree, $7=$ strongly agree. 
Table 7: Results on wine labels

\begin{tabular}{|c|c|c|c|c|c|c|c|c|c|c|}
\hline \multirow[b]{3}{*}{ Variable } & \multicolumn{10}{|c|}{ Symbolic/experiential aspect of the wine (label) } \\
\hline & \multicolumn{2}{|c|}{ Tasty } & \multicolumn{2}{|c|}{ Quality } & \multicolumn{2}{|c|}{ Value } & \multicolumn{2}{|c|}{ Status } & \multicolumn{2}{|c|}{ Exclusive } \\
\hline & Coef. & SE. & Coef. & SE. & Coef. & SE. & Coef. & SE. & Coef. & SE. \\
\hline \multicolumn{11}{|l|}{ Varietal: } \\
\hline Cabernet Sauv. & -0.164 & $0.080 * *$ & -0.301 & $0.079 * * *$ & 0.037 & 0.074 & -0.565 & $0.083 * * *$ & -0.733 & $0.089 * * *$ \\
\hline Chardonnay & -0.178 & $0.080 * *$ & -0.407 & $0.079 * * *$ & 0.041 & 0.074 & -0.483 & $0.083 * * *$ & -0.580 & $0.089 * * *$ \\
\hline (none) & -0.273 & $0.113 * *$ & -0.250 & $0.112 * *$ & -0.065 & 0.105 & -0.361 & $0.117 * * *$ & -0.437 & $0.125^{* * *}$ \\
\hline Sauv. Blanc & 0.015 & 0.113 & -0.153 & 0.112 & 0.176 & $0.105^{*}$ & -0.236 & $0.117 * *$ & -0.315 & $0.125 * *$ \\
\hline Semillon & -0.166 & 0.138 & -0.061 & 0.137 & 0.132 & 0.128 & -0.408 & $0.144 * * *$ & -0.543 & $0.153 * * *$ \\
\hline Shiraz & -0.044 & 0.113 & -0.216 & $0.112 *$ & 0.231 & $0.105^{* *}$ & -0.546 & $0.117 * * *$ & -0.599 & $0.125 * * *$ \\
\hline Verdelho & -0.597 & $0.159 * * *$ & -0.843 & $0.159 * * *$ & -0.162 & 0.148 & -1.041 & $0.166^{* * *}$ & -0.962 & $0.177 * * *$ \\
\hline \multicolumn{11}{|l|}{ Region: } \\
\hline Barossa & 0.210 & 0.159 & 0.078 & 0.159 & 0.024 & 0.148 & 0.444 & $0.166^{* * *}$ & 0.817 & $0.177 * * *$ \\
\hline Hunter Valley & 0.380 & $0.159 * *$ & 0.267 & $0.159 *$ & 0.128 & 0.148 & 0.729 & $0.166^{* * *}$ & 0.687 & $0.177 * * *$ \\
\hline Margaret River & 0.282 & $0.159 *$ & 0.336 & $0.159 * *$ & 0.210 & 0.148 & 0.481 & $0.166^{* * *}$ & 0.758 & $0.177 * * *$ \\
\hline \multicolumn{11}{|l|}{ Price: } \\
\hline$\$ 15-20$ & -0.012 & 0.138 & 0.166 & 0.137 & -0.221 & $0.128^{*}$ & 0.377 & $0.144 * * *$ & 0.907 & $0.153 * * *$ \\
\hline$\$ 20-30$ & 0.238 & 0.159 & 0.255 & 0.159 & 0.030 & 0.148 & 0.562 & $0.166^{* * *}$ & 1.050 & $0.177 * * *$ \\
\hline$\$ 30$ and over & 0.277 & $0.080 * * *$ & 0.400 & $0.079 * * *$ & -0.055 & 0.074 & 0.628 & $0.083 * * *$ & 0.928 & $0.089 * * *$ \\
\hline \multicolumn{11}{|l|}{ Additional } \\
\hline information & 0.046 & 0.080 & 0.210 & $0.079 * * *$ & 0.176 & $0.074 * *$ & 0.046 & 0.083 & 0.037 & 0.089 \\
\hline Female & 0.152 & $0.043 * * *$ & 0.190 & $0.042 * * *$ & 0.264 & $0.040 * * *$ & 0.139 & $0.044 * * *$ & 0.182 & $0.047 * * *$ \\
\hline \multicolumn{11}{|l|}{ Age: } \\
\hline $25-34$ years & -0.261 & $0.088 * * *$ & -0.280 & $0.088 * * *$ & -0.301 & $0.082 * * *$ & -0.196 & $0.092 * *$ & -0.208 & $0.098 * *$ \\
\hline $35-44$ years & -0.109 & 0.087 & -0.130 & 0.087 & -0.099 & 0.081 & -0.108 & 0.091 & -0.193 & $0.097 * *$ \\
\hline $45-54$ years & 0.031 & 0.087 & -0.003 & 0.087 & -0.135 & $0.081 *$ & -0.149 & 0.091 & -0.109 & 0.097 \\
\hline $55+$ years & -0.002 & 0.091 & -0.033 & 0.091 & -0.117 & 0.085 & 0.003 & 0.095 & -0.055 & 0.101 \\
\hline \multicolumn{11}{|l|}{ Wine } \\
\hline \multicolumn{11}{|l|}{ Involvement: } \\
\hline Consumption & -0.015 & 0.016 & -0.018 & 0.016 & -0.045 & $0.015 * * *$ & 0.022 & 0.017 & 0.024 & 0.018 \\
\hline Knowledge & 0.133 & $0.022 * * *$ & 0.135 & $0.022 * * *$ & 0.134 & $0.020 * * *$ & 0.092 & $0.023 * * *$ & 0.113 & $0.024 * * *$ \\
\hline Detect quality & -0.010 & 0.019 & -0.013 & 0.019 & -0.014 & 0.018 & -0.081 & $0.020 * * *$ & -0.102 & $0.021 * * *$ \\
\hline Constant & 4.158 & $0.199 * * *$ & 4.064 & $0.200 * * *$ & 3.899 & $0.185^{* * *}$ & 3.670 & $0.207 * * *$ & 3.140 & $0.222 * * *$ \\
\hline
\end{tabular}

Dependent variable measurements from a seven-point Likert scale where $1=$ strongly disagree, $7=$ strongly agree. Consumption, knowledge and detecting quality measurements from a seven-point Likert scale where $1=$ strongly disagree, $7=$ strongly agree. 
Reference categories for Varietal, Region, Price and Age are Merlot, Marlborough, under \$15 and 18-24 years, respectively. Variable categories omitted (to avoid multicollinearity) are: Varietals Merlot Cabernet, Pinot Noir and Tawny; and Regions Yarra Valley and Hawke's Bay.

* Significant at $0.10 ; * *$ Significant at $0.05 ; * * *$ Significant at 0.01 . 